\title{
Effects of formoterol, salmeterol or oxitropium bromide on airway responses to salbutamol in COPD
}

\author{
M. Cazzola*, F. Di Perna*+, P. Noschese*, A. Vinciguerra*, F. Calderaro*+, \\ G. Girbino+, M.G. Matera*
}

Effects of formoterol, salmeterol or oxitropium bromide on airway responses to salbutamol in COPD. M. Cazzola, F. Di Perna, P. Noschese, A. Vinciguerra, F. Calderaro, G. Girbino, M.G. Matera. @ERS Journals Ltd 1998.

ABSTRACT: We examined whether a pretreatment with formoterol, oxitropium bromide, or salmeterol might modify the dose-response curves to inhaled salbutamol in patients with stable and partially reversible chronic obstructive pulmonary disease (COPD).

Sixteen outpatients with partially reversible, stable COPD received $24 \mu \mathrm{g}$ formoterol, $50 \mu \mathrm{g}$ salmeterol, $200 \mu \mathrm{g}$ oxitropium bromide, or placebo on four non-consecutive days. Spirometric testing was performed immediately before inhalation of treatment and after $2 \mathrm{~h}$. A dose-response curve to inhaled salbutamol was then constructed using doses of $100,100,200 \mu \mathrm{g}$ and $400 \mu \mathrm{g}$ - that is, a total cumulative dose of $800 \mu \mathrm{g}$. Dose increments were given at $20 \mathrm{~min}$ intervals with measurements being made 15 min after each dose.

Formoterol, salmeterol, or oxitropium bromide elicited a significant increase in forced expiratory volume in one second (FEV1) compared with placebo (mean differences $(L)=$ placebo 0.05 ; formoterol 0.34 ; salmeterol 0.27 ; oxitropium bromide 0.23 ). Dose-dependent increases in FEV1 were seen (mean values $(L)$ before salbutamol and after a cumulative dose of $100,200,400$, and $800 \mu \mathrm{g}=$ placebo: $1.06,1.28,1.35,1.39$, 1.41; formoterol: $1.33,1.37,1.41,1.44,1.44$; salmeterol: $1.30,1.33,1.36,1.39,1.42$; oxitropium bromide: $1.27,1.34,1.37,1.41,1.40)$. Statistical analysis revealed no significant differences in FEV1 and forced vital capacity (FVC) responses to salbutamol after therapy with formoterol, salmeterol, or oxitropium bromide compared with placebo.

This study clearly shows that a pretreatment with a conventional dose of formoterol, salmeterol, or oxitropium bromide does not preclude the possibility of inducing a further bronchodilation with salbutamol in patients suffering from partially reversible chronic obstructive pulmonary disease.

Eur Respir J 1998; 11: 1337-1341.

Although there are several doubts on effect of bronchodilators in the treatment of chronic obstructive pulmonary disease (COPD) because in this pathological disease the bronchial obstruction is very often "irreversible", many clinicians think that it is necessary to treat patients suffering from COPD with bronchodilator drugs $[1,2]$. The consensus guidelines of a Canadian Thoracic Society Workshop group [3] and the most recent guidelines from the American Thoracic Society [4] suggest the inhaled administration of an anticholinergic agent as first-line therapy in stable COPD; however, the introduction of long acting $\beta_{2}$-adrenoceptor agonists (e.g., salmeterol and formoterol) gives physicians additional therapeutic options. In fact, formoterol induced an improvement in airflow limitation in chronic obstructive airway disease [5], and salmeterol resulted in a definite reduction in the bronchial obstruction after $1 \mathrm{yr}$ of treatment [6].

Worsening of the underlying bronchospasm may be associated with acute exacerbations of COPD. As the airway obstruction becomes more severe, the therapeutic option is to add a short acting inhaled $\beta_{2}$-agonists, such as salbutamol, as rescue medication to cause rapid relief of bron-
*Divisione di Pneumologia e Allergologia e Settore di Farmacologia Clinica Respiratoria, Ospedale A. Cardarelli, Napoli, Italy. +Istituto di Malattie Respiratoire, Facoltà di Medicina e Chirurgia, Università, Messina, Italy.

Correspondence: M. Cazzola

Via del Parco Margherita 24

80121 Napoli

Italy

Fax: 39817473331

Keywords: Chronic obstructive pulmonary disease

formoterol

oxitropium bromide

salbutamol

salmeterol

Received: July 301997

Accepted after revision January 71998 chospasm. Unfortunately, the recommended dosage may increase during acute exacerbations [7]; it is usually greater than the conventional dosage via a metered-dose inhaler (MDI) [8]. However, a pretreatment with formoterol and salmeterol could reduce the airway's responses to repeated doses of a short acting inhaled $\beta_{2}$-agonist. In fact, formoterol and salmeterol are partial $\beta_{2}$-receptor agonists and in the presence of a full $\beta$-agonist they may act as a $\beta_{2}$-antagonist [9]. In fact, a partial $\beta$-adrenoceptor agonist exhibits opposite agonist and antagonist activity depending on the prevailing degree of adrenergic tone or the presence of a $\beta$-adrenoceptor agonist with higher intrinsic activity.

Against this background, we felt it useful to examine if a pretreatment by formoterol or salmeterol might modify the dose-response curves to inhaled salbutamol in patients with stable and partially reversible COPD. Moreover, we have also investigated the effect of a pretreatment by oxitropium bromide on these dose-response curves since oxitropium and salbutamol are distinct classes of drugs by differing mechanisms of action and, therefore, it seems reasonable to expect that they might have additive, complementary effects when combined. 


\section{Patients and methods}

We assessed 16 outpatients with coexisting moderate to severe COPD, but in a stable phase of disease, and with reversible airway obstruction, who gave their informed consent. All fulfilled the criteria proposed by the American Thoracic Society [4]: i.e. they were $>40$ yrs of age, current or former smokers ( $>10$ pack-yrs) without a history of asthmatic attacks, reporting either chronic cough with or without sputum production or dyspnoea when walking quietly on level ground, or both, had had no change in symptom severity or treatment in the preceding 4 weeks, had shown no signs of a respiratory tract infection in the month preceding or during the trial, were not taking oral or inhaled corticosteroids for at least 3 months prior and had a forced expiratory volume in one second (FEV1) $<65 \%$ of predicted normal and a forced vital capacity (FVC) $<70 \%$ after bronchodilators had been withheld for $24 \mathrm{~h}$ and a best post-bronchodilator FEV1/FVC of less than 0.7. Patients with allergic rhinitis, atopy, skintest positivity or with a total blood eosinophil count $>400$ cells $\cdot \mathrm{mm}^{-3}$ were excluded. Patients were excluded also if they had any coexisting cardiovascular or lung disorder. At an initial screening visit, patients were required to demonstrate an increase of FEV1 of at least $15 \%$ in response to inhaled $200 \mu \mathrm{g}$ salbutamol.

No oral bronchodilators were permitted for one week before and during the study, whereas inhaled short acting bronchodilator drugs and inhaled long acting bronchodilator agents were not permitted for at least $12 \mathrm{~h}$ and $24 \mathrm{~h}$ prior to each test, respectively. Consumption of cola drinks, coffee, tea, and smoking in the hours before and during the investigation were also avoided.

The study, which was conducted according to the rules of the declaration of Helsinki, was performed using a double-blind, crossover, randomized design. Patients received two puffs of salmeterol $(50 \mu \mathrm{g})$, formoterol $(24 \mu \mathrm{g})$, oxitropium bromide $(200 \mu \mathrm{g})$, or placebo, which were all inhaled from matched MDI and holding chamber (AeroChamber) with mouthpiece, on four non-consecutive days. Spirometric testing was performed according to the procedures described in the American Thoracic Society's 1987 update [10]. Three acceptable forced expiratory manoeuvres were performed in order to obtain two reproducible results for FVC and FEV1. The highest FEV1, obtained from one or the other of the reproducible curves, was kept for analysis. Measurements were performed immediately before inhalation of treatment and two hours post inhalation.

Two hours after the inhalation of each treatment, following planned spirometries, a dose-response curve to inhaled salbutamol was constructed using a dose of 100,100 , 200 and $400 \mu \mathrm{g}$ - that is a total cumulative dose of $800 \mu \mathrm{g}$. Salbutamol was also administered from a MDI and holding chamber (AeroChamber Trudell Medical, London, Ontario, Canada) with mouthpiece. Dose increments were given at 20 min intervals with measurements being made $15 \mathrm{~min}$ after each dose.

A standard lead II electrocardiogram was monitored and recorded with paper speed set at $25 \mathrm{~mm} \cdot \mathrm{s}^{-1}$. Heart rate was calculated from the mean of five consecutive R-R intervals.

The functional indices' increases from baseline after formoterol, salmeterol, oxitropium bromide, and placebo were assessed. The maximum FEV1 value during the doseresponse curve to salbutamol was chosen as the primary outcome variable to compare the four treatments. Analysis of spirometric data and those of pulse rate for each treatment were performed using the Student's t-test for paired variables. Mean responses were also compared by multifactorial analysis of variance (ANOVA) to establish any significant overall effect between all four treatments. In the presence of a significant overall ANOVA, Duncan's multiple range testing with $95 \%$ confidence limits was used to identify where differences were significant. A probability level of $p<0.05$ was considered as being of significance for all tests.

\section{Results}

All patients completed the four-day study. There were no significant differences between the baseline spirometric values and heart rates of the four treatment groups (FEV1 values; $\mathrm{p}=0.46$ ) (table 1).

Table 1. - Baseline values and changes in FEV $1, F V C$ and $\mathrm{HR} 2 \mathrm{~h}$ after placebo, formoterol, salmeterol or oxitropium and maximum change after cumulative doses of salbutamol

\begin{tabular}{|c|c|c|c|c|}
\hline & Placebo & Formoterol $(24 \mu \mathrm{g})$ & Salmeterol $(50 \mu \mathrm{g})$ & Oxitropium $(200 \mu \mathrm{g})$ \\
\hline \multicolumn{5}{|l|}{ FEV1 L } \\
\hline Baseline & $1.01(0.79-1.21)$ & $0.99(0.77-1.21)$ & $1.03(0.80-1.26)$ & $1.04(0.81-11.27)$ \\
\hline $\begin{array}{l}\text { Change from baseline } \\
\text { after } 2 \mathrm{~h}\end{array}$ & $0.05(0.01-0.09)$ & $0.34(0.24-0.43)$ & $0.27(0.19-0.34)$ & $0.23(0.15-0.30)$ \\
\hline $\begin{array}{l}\text { Maximum change from } \\
\text { baseline after salbutamol }\end{array}$ & $0.42(0.32-0.52)$ & $0.48(0.37-0.59)$ & $0.39(0.28-0.40)$ & $0.41(0.33-0.49)$ \\
\hline \multicolumn{5}{|l|}{ FVC L } \\
\hline Baseline & $1.82(1.43-2.21)$ & $1.81(1.41-2.21)$ & $1.84(1.45-2.23)$ & $1.81(1.41-2.21)$ \\
\hline $\begin{array}{l}\text { Change from baseline } \\
\text { after } 2 \mathrm{~h}\end{array}$ & $0.03(0-0.06)$ & $0.39(0.30-0.48)$ & $0.31(0.25-0.38)$ & $0.35(0.29-0.41)$ \\
\hline $\begin{array}{l}\text { Maximum change from } \\
\text { baseline after salbutamol }\end{array}$ & $0.52(0.39-0.65)$ & $0.55(0.40-0.70)$ & $0.52(0.35-0.69)$ & $0.59(0.44-0.74)$ \\
\hline \multicolumn{5}{|l|}{ HR beats $\cdot \mathrm{min}^{-1}$} \\
\hline Baseline & $80.7(76.3-85.1)$ & $80.0(75.5-84.5)$ & $77.9(73.1-82.4)$ & $77.7(72.7-82.7)$ \\
\hline $\begin{array}{l}\text { Change from baseline } \\
\text { after } 2 \mathrm{~h}\end{array}$ & $2.1(-2.1-6.3)$ & $1.3(-2.7-5.3)$ & $4.4(0.5-8.3)$ & $0.4(-5.7-6.5)$ \\
\hline $\begin{array}{l}\text { Maximum change from } \\
\text { baseline after salbutamol }\end{array}$ & $4.2(-0.2-8.6)$ & $7.5(1.4-13.6)$ & $11.2(5.1-17.3)$ & $8.2(2.4-14.0)$ \\
\hline
\end{tabular}

Values are mean (95\% confidence interval (CI)). FEV1: forced expiratory volume in one second; FVC: forced vital capacity; HR: heart rate. 


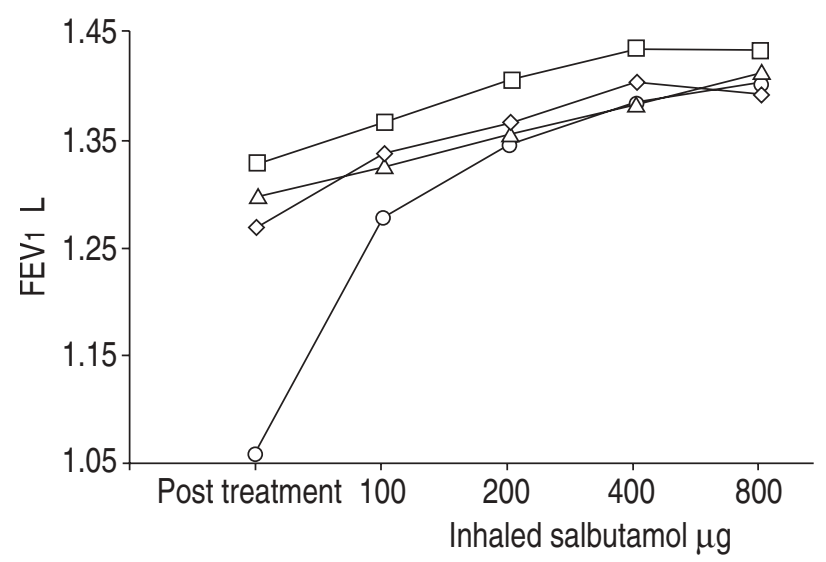

Fig. 1. - Mean dose-response curves to inhaled salbutamol construction $2 \mathrm{~h}$ after inhaling placebo $(\mathrm{O})$, formoterol $(24 \mu \mathrm{g} ; \square)$, salmeterol $(50$ $\mu \mathrm{g} ; \Delta)$, or oxitropium $(200 \mu \mathrm{g} ;>)$ for forced expiratory volume in one second (FEV1).

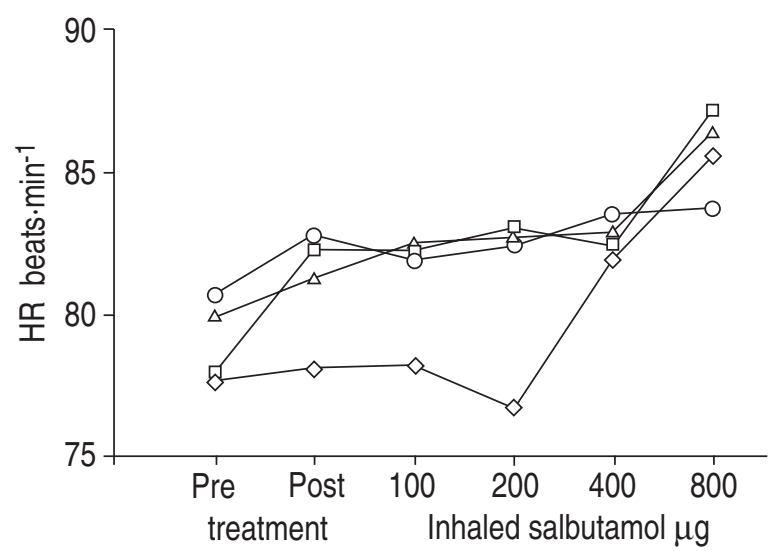

Fig. 2. - Mean dose-response curves to inhaled salbutamol construction $2 \mathrm{~h}$ after inhaling placebo (O), formoterol $(24 \mu \mathrm{g} ; \square)$, salmeterol (50 $\mu \mathrm{g} ; \Delta)$, or oxitropium $(200 \mu \mathrm{g} ; \diamond)$ for heart rates (HR).

Formoterol, salmeterol and oxitropium bromide elicited an increase in FEV1 (mean differences $(\mathrm{L})=$ formoterol 0.34 (95\% confidence interval (CI) $0.24-0.43$ ); salmeterol 0.27 (95\% CI 0.19-0.34); oxitropium bromide 0.23 (95\% CI 0.15-0.30)) and in FVC (mean differences $(\mathrm{L})=$ formoterol 0.39 (95\% CI 0.30-0.48); salmeterol 0.31 (95\% CI 0.25-0.37); oxitropium bromide 0.35 (95\% CI 0.29 to $0.41)$ ) which was significant $(\mathrm{p}<0.05)$ when compared with placebo (table 1). There were no significant differences between the bronchodilator responses to formoterol, salmeterol, and oxitropium (FEV1 values; $\mathrm{p}=0.29$ ).

Salbutamol induced a large dose-dependent increase in FEV1 (fig. 1) and FVC after placebo and a further increase after formoterol, salmeterol, or oxitropium. However, $800 \mu \mathrm{g}$ salbutamol did not induce further benefit when compared with $400 \mu \mathrm{g}$ salbutamol. Maximum values of bronchodilation of all the four treatments were statistically different $(\mathrm{p}<0.05)$ from their postinhalational baseline levels. In the main analysis (based on the maximum FEV1 obtained during the dose-response curve to salbutamol) the within-subject variability was $0.1037 \mathrm{~L}$. Therefore, this $4 \times 4$ crossover study with 16 patients had an $80 \%$ power of detecting a difference in FEV1 of at least $0.11 \mathrm{~L}$ between treatments. Statistical analysis showed no significant differences $(\mathrm{p}=0.61)$ between the four treatments.

We were unable to find statistically significant differences $(p>0.05)$ in maximum heart responses to salbutamol after treatment with the three bronchodilators when compared with placebo (table 1; fig. 2).

\section{Discussion}

This study shows that an acute pretreatment with a long acting $\beta_{2}$-agonist or an anticholinergic drug does not reduce the possibility of inducing a further bronchodilation with a short acting $\beta_{2}$-agonist in patients who are suffering from COPD and present a partially reversible bronchospasm. It is difficult to draw certain conclusions regarding the synergistic, additive or antagonistic actions of salbutamol following long acting $\beta_{2}$-agonists or oxitropium unless compared with formoterol, salmeterol and oxitropium limbs alone. Such a design would be interesting, but it is complex to perform. Nevertheless, we underline that our study had an $80 \%$ power of detecting a difference in FEV1 of at least $0.11 \mathrm{~L}$ between treatments. The absolute increase in FEV1 necessary to distinguish, with $95 \%$ confidence, between natural variability and a response to bronchodilator in patients with COPD is $0.16 \mathrm{~L}$ [11]

Salbutamol was chosen to construct the dose-response curves although it has been shown that this short acting $\beta_{2}$-agonist acts as a partial $\beta_{2}$-agonist/antagonist and inhibits the effects of endogenous adrenaline at extrapulmonary $\beta_{2}$-receptors in normal subjects [12]; moreover, a subsensitivity to salbutamol has been demonstrated after chronic dosing with salmeterol [13]. However, our choice was suggested by the evidence that salbutamol exhibits in vitro partial $\beta_{2}$-agonist activity at cardiac $\beta_{2}$-adrenoceptors and full agonist activity at airway $\beta_{2}$-adrenoceptors [14], produces more relaxant effect than salmeterol at very high level of precontraction in the guinea-pig isolated trachea [15], and, finally, acts in vivo as a partial agonist only in a state of high adrenergic tone [13], but this is not the case of patients with stable COPD. In any case, our data are in agreement with those of Sмүтн et al. [16], who found a good rise in FEV1 after addition of increasing doses of salbutamol in asthmatic patients pretreated with salmeterol $50 \mu \mathrm{g}$ (but this rise became progressively smaller after salmeterol 100 and $200 \mu \mathrm{g}$ ).

The evidence that prior treatment with formoterol and salmeterol does not alter bronchodilator response to repeated doses of a short acting $\beta_{2}$-agonist conflicts with data of several in vitro researches. In fact, Dougall et al. [17], using adrenaline and isoprenaline as agonists, noted significantly less steep concentration-effect curves in the presence of salmeterol as compared to control curves. More, recently, NALINE et al. [18] showed that when isolated human bronchi were incubated in the presence of formoterol, a significant (1 log unit) displacement of the concentration-response curves to adrenaline was observed with long acting $\beta_{2}$-agonist at a concentration giving a maximal effect. With salmeterol, the concentration-res-ponse curves were displaced by $0.6 \log$ units at a concentration producing 17-26\% of relaxant effect, and by $1.7 \log$ units at a concentration producing $60 \%$ of the relaxant effect. In particular, KÄLESTRÖM et al. [19] reported that in guinea-pig, salbutamol and several other $\beta_{2}$-agonists show-ed concen- 
tration-effect curves that tended to be less steep in the presence of salmeterol.

It is interesting to highlight that Grove and LipworTh [20] have documented high doses of formoterol $(72 \mu \mathrm{g})$ and salmeterol $(300 \mu \mathrm{g})$ which, in the presence of endogenous adrenaline or exogenous fenoterol, act as $\beta_{2}$-receptor antagonists in terms of antagonising the extrapulmonary responses to fenoterol, as evidenced by the potentiation of exercise-induced hyperkalaemia and the attenuation of hypokalaemic, tremor, and heart rate responses in normal subjects. However, in a second study which included 10 patients with stable asthma, the same researchers observed that prior treatment with low doses of salmeterol ( 25 $\mu \mathrm{g})$ and formoterol $(12 \mu \mathrm{g})$ had no significant effects on the bronchodilator or systemic $\beta_{2}$-receptor-mediated responses to fenoterol [21].

In contrast to the study of Grove and Lipworth [21], we have used the recommended doses of salmeterol $(50 \mu \mathrm{g})$ and formoterol $(24 \mu \mathrm{g})$. These doses were chosen as we were expecting that formoterol and salmeterol did not induce the maximum bronchodilation. In fact, we have previously examined the dose-response effect curves to formoterol and salmeterol in a population of patients with partially reversible severe COPD [22]. Both drugs induced a functional improvement lasting $12 \mathrm{~h}$, but formoterol (12-36 $\mu \mathrm{g})$ caused a dose-dependent increase in FVC, FEV1 and forced mid-expiratory flow (FEF25-75\%), where-as salmeterol $(75 \mu \mathrm{g})$ did not elicit a further increase in bronchodilation than salmeterol $(50 \mu \mathrm{g})$. Moreover, at the recommended dose $(50 \mu \mathrm{g})$, salmeterol was more active than formoterol (12 and $24 \mu \mathrm{g}$ ), but less effective than formoterol $(36 \mu \mathrm{g})$. These findings clearly indicated that further bronchodilation was still possible.

A number of clinical studies have shown a benefit of combining a short acting $\beta_{2}$-agonist with anticholinergic agents such as ipratropium and oxitropium in COPD [23]. In fact, since $\beta_{2}$-agonists and anticholinergic agents are distinct classes of drugs with different mechanisms of action, an additive effect may be expected [24-26]. Prior attenuation of vagal tone by anticholinergic drug permits optimal achievable dilatation to be attained by subsequent inhalation of a short acting $\beta_{2}$-agonist. Furthermore, there are prejunctional inhibitory $\beta_{2}$ receptors on cholinergic fibres which might conceivably result in attenuation of resting vagal tone, in addition to direct $\beta_{2}$-mediated smooth muscle relaxation [27]. Nevertheless, it seems that there is no significant benefit of adding a $\beta$-agonist when the antimuscarinic agent has been given previously [28]. Our data showed that adding salbutamol to oxitropium induced further bronchodilation and the peak values obtained during the dose-responses curves following treatment with oxitropium were not significantly different from those obtained after salmeterol or formoterol. However, we observed an absence of difference between oxitropium + salbutamol versus placebo + salbutamol. Evidence is mounting to support the clinical practice of combining an anticholinergic bronchodilator with a $\beta_{2}$-agonist only in patients with COPD who exhibit suboptimal response to first-line therapy [29]. It is conceivable that the subjects studied in this specific clinical situation reached the top of their bronchodilation response curve after inhalation of salbutamol. A positive correlation between maximum bronchodilator response and the dose of $\beta_{2}$-adrenoceptor agonist used is not always observed. However, a $50 \%$ in- crease in FEV1 is obtained with $400 \mu \mathrm{g}$ salbutamol and an increase in the dose of this agent may produce further increases in FEV1 [30]. In any case, the results of this study apparently refute the assertion that airway obstruction secondary to increased vagal tone, and is the only dominant reversible element in patients suffering from COPD.

In conclusion, the results of this study support the use of salbutamol as rescue medication for rapid relief of bronchospasm in patients suffering from partially reversible chronic obstructive pulmonary disease, even after conventional inhaled doses of long acting $\beta_{2}$-adrenoceptor agonists or anticholinergic drugs. Obviously, we have yet to establish whether the long-term treatment with these long acting bronchodilating agents may have a different impact on the dose-response to a short acting $\beta_{2}$-agonist.

Acknowledgement: The authors thank P. Fina for statistical analysis.

\section{References}

1. Anthonisen NR, Wright EC, IPPB Trial Group. Bronchodilator response in chronic obstructive pulmonary disease. Am Rev Respir Dis 1986; 133: 814-819.

2. Postma DS, de Vries K, Koeter GH, Sluiter HJ. Independent influence of reversibility of airflow obstruction and nonspecific hyperreactivity on the long-term course of lung function in chronic airflow obstruction. Am Rev Respir Dis 1986; 134: 276-280.

3. Chapman KR, Bowie OM, Goldstein RS, et al. Guidelines for the assessment and management of chronic obstructive pulmonary disease. Canadian Thoracic Society Workshop Group. Can Med Ass J 1992; 147: 420-428

4. American Thoracic Society. Standards for the diagnosis and care of patients with chronic obstructive pulmonary disease. Am J Respir Crit Care Med 1995; 152: S72S120.

5. Schultze-Werninghaus G. Multicenter 1-year trial on formoterol, a new long-acting beta 2 -agonist, in chronic obstructive airway disease. Lung 1990; 168 (Suppl.): 83-89.

6. Di Lorenzo G, Barbagallo Sangiorgi G, Ravinetto R, Squassante L, Zanferrari G. Inhaled salmeterol and oral theophylline in patients with chronic bronchitis: a multicentre clinical comparison. Giorn It Med Torac 1995; Suppl. 53.

7. Jaeschke R, Guyatt GH, Cook O, et al. The effect of increasing doses of $\beta$-agonists on airflow in patients with chronic airflow limitation. Respir Med 1993; 87: 433438.

8. Newhouse N, Dolovich M. Aerosol therapy: nebulized vs metered dose inhaler. Chest 1987; 91: 799-800.

9. Lipworth BJ, Grove A. Evaluation of partial $\beta$-adrenoceptor agonist activity. Br J Clin Pharmacol 1997; 43: 914.

10. American Thoracic Society. Standardization of spirometry - 1987 update. Am Rev Respir Dis 1987; 136: 12851298.

11. Tweeddale PM, Alexander F, McHardy GJR. Short term variability in FEV1 and bronchodilator responsiveness in patients with obstructive ventilatory defects. Thorax 1987; 42: 487-490.

12. Grove A, McFarlane LC, Lipworth DJ. Expression of the $\beta_{2}$-adrenoceptor partial agonist/antagonist activity of salbutamol in states of low and high adrenergic tone. Thorax 1995; 50: 134-138. 
13. Grove A, Lipworth BJ. Bronchodilator subsensitivity to salbutamol after twice daily salmeterol in asthmatic patients. Lancet 1995; 346: 201-206.

14. Wagner J, Reinhardt D, Schumann HJ. Comparison of the bronchodilator and cardiovascular actions of isoprenaline, Th 1165a, terbutaline and salbutamol in cats and isolated organ preparations. Res Exp Med 1974; 162: 49-62.

15. Lindén A, Bergendal A, Ullman A, Skoogh B-E, Löfdahl C-G. Salmeterol, formoterol, and salbutamol in the isolated guinea pig trachea: differences in maximum relaxant effect and potency but not in functional antagonism. Thorax 1993; 48: 547-553.

16. Smyth ET, Pavord ID, Wong CS, Wisniewski AFZ, Williams J, Tattersfield AK. Interaction and dose equivalence of salbutamol and salmeterol in patients with asthma. $\mathrm{Br}$ Med J 1993; 306: 543-545.

17. Dougall IG, Harper D, Jackson DM, Leff P. Estimation of the efficacy and affinity of the $\beta_{2}$-adrenoceptor agonist salmeterol in guinea-pig trachea. Br J Pharmacol 1991; 104: 1057-1061.

18. Naline E, Zhang Y, Qian Y, et al. Relaxant effects and durations of action of formoterol and salmeterol on the isolated human bronchus. Eur Respir J 1994; 7: 914920.

19. Käleström B-L, Sjöberg J, Waldeck B. The interaction between salmeterol and $\beta_{2}$-adrenoceptor agonists with higher efficacy on guinea-pig trachea and human bronchus in vitro. Br J Pharmacol 1994; 113: 687-692.

20. Grove A, Lipworth BJ. Evaluation of the $\beta_{2}$-adrenoceptor agonist/antagonist activity of formoterol and salmeterol. Thorax 1996; 51: 54-58.

21. Grove A, Lipworth BJ. Effects of prior treatment with salmeterol and formoterol on airway and systemic $\beta_{2}$ responses to fenoterol. Thorax 1996; 51: 585-589.

22. Cazzola M, Matera MG, Santangelo G, Vinciguerra A,
Rossi F, D'Amato G. Salmeterol and formoterol in partially reversible severe chronic obstructive pulmonary disease: a dose-response study. Respir Med 1995; 89: 357-362.

23. Combivent Inhalation Aerosol Study Group. In chronic obstructive pulmonary disease, a combination of ipratropium and albuterol is more effective than either agent alone. Chest 1994; 105: 1411-1419.

24. Imhof E, Elasser S, Karrer W, et al. Comparison of bronchodilator effects of fenoterol/ipratropium bromide and salbutamol in patients with chronic obstructive lung disease. Respiration 1993; 60: 84-88.

25. Koyama H, Nishimura K, Ikeda A, Izumi T. A comparison of the bronchodilating effects of oxitropium bromide and fenoterol in patients with chronic obstructive pulmonary disease. Chest 1993; 104: 1743-1747.

26. Nishi K, Fujimura K, Myou S, et al. Comparison of the bronchodilator activities of oxitropium bromide, fenoterol, and their combination in patients with chronic obstructive pulmonary disease and bronchial asthma. Clin Auton Res 1993; 3: 41-44.

27. Rhoden KJ, Meldrum LA, Barnes PJ. Inhibition of cholinergic neurotransmission in human airways by $\beta_{2}$-adrenoceptors. J Appl Physiol 1988; 65: 700-705.

28. Newnham DM, Dhillon DP, Winter JH, et al. Bronchodilator reversibility to low and high doses of terbutaline and ipratropium bromide in patients with chronic obstructive pulmonary disease. Thorax 1993; 48: 1151-1155.

29. Sobol BJ. Some problems encountered in the evaluation of bronchodilator therapy. Chest 1978; 73 (Suppl.): 991992.

30. Barclay J, Whiting B, Addis GJ. The influence of theophylline on maximal response to salbutamol in severe chronic obstructive pulmonary disease. Eur J Clin Pharmacol 1982; 22: 389-393. 